\title{
Occurrence, isolation and DNA identification of Streptococcus thermophilus involved in Algerian traditional butter 'Smen'
}

\author{
Farid Bensalah $^{1 \star}$, Asmaa Labtar ${ }^{1}$, Christine Delorme ${ }^{2}$ and Pierre Renault ${ }^{2}$ \\ ${ }^{1}$ Faculté des Sciences, Département de Biologie, LGM (Laboratoire de Génétique Microbienne), Université Es-Sénia, \\ Oran 31000, Algérie. \\ ${ }^{2}$ INRA-CRJ, Institut National de la Recherche Agronomique, Micalis Institute, Département de Microbiologie et Chaîne \\ Alimentaire. 78352 Jouy-En- Josas, cedex, France. \\ Accepted 19 October, 2011
}

\begin{abstract}
Streptococcus thermophilus isolates from traditional butter 'Smen', a fermented product from cow's and ewe's milk in arid area was subjected to taxonomical investigations. The identification procedure included phenotypic approaches, molecular characterization by using genus polymerase chain reaction (PCR) amplifications for sodA gene encoding the manganese-dependant superoxide dismutase $A$, and species-specific primers from gene encoding glucose kinase ( $g / c K)$, gene encoding DNA polymerase III $(d n a E)$ and gene encoding threonyl-tRNA synthetase (thrS) housekeeping genes in order to distinguish among reference, and wild strains of $S$. thermophilus and for their differentiation from Enterococcus spp. A total of 12 strains were tested by DNA identification analysis and these indigenous isolates were unambiguously characterised by their housekeeping gene profiles. Finally, four genotypes were recognised. To our knowledge, this is the first report on the isolation and molecular characterization of S. thermophilus strains from fermented milk transformed into home-production butter provided from Southern West Algeria. These results are of particular interest as they favour the selection of future cultures starters as $\mathbf{S}$. thermophilus from traditional dairy products. It is, therefore, of great importance to preserve the genetic pool of the wild strains.
\end{abstract}

Key words: Streptococcus thermophilus, traditional butter, PCR, Enterococcus, DNA, species-specific primer.

\section{INTRODUCTION}

The microbial composition of traditional dairy products and, particularly, of European artisanal cow's and ewe's fermented milk and cheeses, have been subjected to microbiological investigation at genus and species level (Tornadjio et al., 1995; Cogan et al., 1997; Mannu et al., 2000; Mannu and Paba, 2002; Alegría et al., 2009; Secchi et al., 2011). Many indigenous fermented foods from Algeria are based on lactic fermentation from cow's and ewe's milk (Bensalah et al., 2009). Among these,

*Corresponding author. E-mail: bensalahfarid@yahoo.fr.

Abbreviation: PCR, Polymerase chain reaction; glcK, gene encoding glucose kinase; dnaE, gene encoding DNA polymerase III; thrS, gene encoding threonyl-tRNA synthetase.
'Smen' is a traditional butter, which, so far has not been investigated for microbiological genotypic strains characterization. The nature of this fermented product is different from one region to another and depends on the local indigenous microflora; which in turn reflects the climatic conditions of the area. However, there is very little information on strain composition within species, and on the specific contribution of each wild strain to the lactic fermentation. Moreover, the study of strain heterogeneity in African traditional butter (El-Baradei et al., 2008; Ongol and Asano, 2009), and cheese starters is believed to be of great importance to the dairy industry (Girrafa et al., 1998).

Fermented milk 'leben' or 'rayeb' (Elotmani et al., 2002; Hegazi, 1988; Bensalah et al., 2009) can be eaten fresh or suffers a churning and creaming in goatskin called 
'Chekoua'. Skimming is usually done in the morning; gourd is half filled with milk fermented, then strained by swelling, and then the 'Chekoua' is tied and shaken vigorously for half an hour. The formation of fat globules is considered by the sound change that occurs within the skin. To assist the agglomeration of particles of butter, water is usually added, hot or cold depending on the temperature of milk. The fresh butter is removed manually in a single lump called 'Zebda' which is transformed into 'Smen' by washing with salt water. 'Smen' has a very strong smell, easily recognizable during ripening. Implication of Streptococcus thermophilus in Egyptian artisanal butter 'zabady' was reported recently (El-Baradei et al., 2008). This strain is an essential microorganism in the manufacture of many types of fermented dairy products, occurring in natural as well as commercial starter cultures (Coppola et al., 1998; Delorme, 2008), and the increasing number of commercial strains available used as starters requires rapid and reliable methods to accurately differentiate strains at both species and strain levels in pure and mixed cultures in order to protect patent rights and eliminate risks of use confusion (Ramos and Harlander, 1990; Moschetti et al., 1998). Enterococcus strains can harbour specific biochemical traits that are essential in the manufacture of various fermented milk products, and some strains are technologically exploited as functional starters or probiotics (Giraffa et al., 1997; Franz et al., 1999; Bensalah et al., 2006). Enterococci has also been implicated in the spoilage of processed meats (Franz and Holy, 1996) and include strains that have been recognized as emerging human pathogens mostly in nosocomial urinary tract infections and bacteremias (Giraffa et al., 2000; Martinez and Baquero, 2002).

In the last few years, the development of new methods involving various DNA-based typing techniques (Farber, 1996), widely used in epidemiological studies for the identification of medically important bacterial strains (Kuhn et al., 1995; Descheemaeker et al., 1997), has opened up new perspectives for typing strains from raw milk and from traditional cheeses (Bouton et al., 1998; Desmasures et al., 1998). It was previously reported that a genus-specific PCR assay based on the use of degenerate primers enabled amplification of an internal fragment representing approximately $85 \%$ of the $\operatorname{sod} A$ gene encoding a manganese-dependent superoxide dismutase (Mn-SOD) in various gram-positive bacteria including genera of Streptococcus (Poyart et al., 1998) and Enterococcus (Poyart et al., 1995). The sodA gene has been identified as a target for the identification of mycobacteria (Zolg and Philippi-Schulz, 1994) and staphylococci at the species level by PCR (Poyart et al., 2001). Another Streptococcus species-specific, PCRbased identification method was reported recently that utilises the housekeeping gene encoding glucose kinase ( $g / c K)$, gene encoding DNA polymerase III (dnaE) and gene encoding threonyl-tRNA synthetase (thrS) (Delorme et al., 2007), and the oligonucleotide primers from the intergenic sequences 16S-23S rRNA (Tissala-Timisjarvi and Alatossava, 1997).

Moreover, since little is known about the involvement of thermophilic cocci with Algerian artisanal foods, this study was aimed at characterizing phenotypically and genotypically, the streptococci associated with the traditional fermented cow's and ewe's raw milk transformed into home-production butter provided from southern west Algeria. We applied the developed methodology of genus and species-specific primers from sodA, glcK, dnaE and thrS housekeeping genes in order to distinguish among reference, and wild strains of $S$. thermophilus and for their differentiation from Enterococcus spp.

\section{MATERIALS AND METHODS}

\section{Sampling and bacterial strains}

Six samples of cow's and ewe's traditional butter 'Smen' were obtained from individual households in rural arid area. Samples were collected in sterile small bottles and stored in Laboratoire de Génétique Microbienne, Es-Sénia, Algeria (LGM) under refrigeration at $4^{\circ} \mathrm{C}$ until use. Reference strains representing four Gram-positive species were used in this study and were provided from INRA collection (Jouy-En-Josas, France). These included $S$. thermophilus CNRZ 1066, Enterococcus faecalis $\mathrm{JH} 2-2$, Enterococcus faecium $64 / 3$ and Corynebacterium glutamicum ATCC 13032.

\section{Isolation and phenotypic characterization of selected isolates}

Serials dilutions of homogenized $10 \mathrm{~g}$ of 'Smen' samples in $90 \mathrm{ml}$ sterile solution saline $0.85 \% \mathrm{NaCl}$ were used for microbial isolation with M17 agar (Terzaghi and Sandine, 1975) containing $1 \%$ lactose (LM17). Plates were incubated anaerobically at 37,45 or $50^{\circ} \mathrm{C}$ for 48 to $72 \mathrm{~h}$ for isolation of thermophilic streptococci. Identification was carried out according to previously published characterization schemes (Devriese et al., 1993; Moschetti et al., 1998; Muller et al., 2001; Michaylova et al., 2007). Gram staining, catalase activity, ammonia production from arginine and gas production from glucose were determined. Tests for growth on Slanetz-Bartley (SB) medium, in $\mathrm{M} 17$ broth at $10^{\circ} \mathrm{C}, \mathrm{pH}$ value adjusted to 9.6 and with $\mathrm{NaCl} 6.5 \%$ were performed for all the isolates. Colonies morphology were determined for overnight cultures by using phase-contrast microscopy and all isolates were stored in liquid cultures with $15 \%$ glycerol at $-80^{\circ} \mathrm{C}$.

\section{Oligonucleotides}

The first preliminary phenotypic investigation was followed by using the nucleotide sequences of internal fragment with PCR identification analysis. Streptococcus /Enterococcus genus-specific primers sodAd1/sodAd2 (encoding superoxide dismutase) as previously described (Poyart et al., 1998, 2000) and housekeeping genes of Streptococcus species-specific primers from glcK, dnaE and thrS, (Delorme et al., 2007) were used in this study.

\section{DNA template preparation}

Template DNA was prepared by a modification of the method of 
Table 1. PCR primers.

\begin{tabular}{lll}
\hline Primer & Sequence & Product size (bp) \\
\hline sodAd1 (universel-F) & 5'-CITAYICITAYGAYGCIYTIGARCC- 3' & 438; Enterococcus \\
sodAd2 (universel-R) & 5'-ARRTARTAIGCRTGYTCCCAIACRTC-3' & 480; Streptococcus \\
& 5'-TGGGCAGAAACTCAAGA-3' & \\
Streptococcus thremophilus (glcK) & 5'-AACACCACCACCGATAAC-3' & 470 \\
& 5'-GGACTGGGAGCCTGGGAT-3' & \multirow{2}{*}{480} \\
Streptococcus thremophilus (dnaE) & 5'-ACTCCCTGCAGCAGACCC-3' & \\
& 5'-ATCACTGAAGATGGAAGC-3' & \multirow{2}{*}{497} \\
\hline
\end{tabular}

$\mathrm{I}=\mathrm{A}, \mathrm{T}, \mathrm{G}$ or $\mathrm{C} ; \mathrm{Y}=\mathrm{C}$ or $\mathrm{T} ; \mathrm{R}=\mathrm{A}$ or $\mathrm{G}$.

Moschetti et al. (1998). Total DNA was extracted from $100 \mu \mathrm{l}$ of overnight cultures which was picked from one colony and resuspended in M17 broth. Cells were pelleted in a microcentrifuge at $8000 \times g$ for $5 \mathrm{~min}$, resuspended in $20 \mu \mathrm{l}$ of GeneReleaser ${ }^{\mathrm{TM}}$ (Bio Ventures, Inc.) and lysed using PCR program as follows: $65^{\circ} \mathrm{C}$ for $30 \mathrm{~s}, 8^{\circ} \mathrm{C}$ for $30 \mathrm{~s}, 65^{\circ} \mathrm{C}$ for $1 \mathrm{~min} 30 \mathrm{~s}, 97^{\circ} \mathrm{C}$ for $3 \mathrm{~min}, 8^{\circ} \mathrm{C}$ for 1 $\min , 65^{\circ} \mathrm{C}$ for $3 \mathrm{~min}, 97^{\circ} \mathrm{C}$ for $1 \mathrm{~min}, 65^{\circ} \mathrm{C}$ for $1 \mathrm{~min}$ and $80^{\circ} \mathrm{C}$ for 5 $\min$.

Amplification of internal part from sodA gene by using degenerate primers

PCR procedure was performed in $25 \mu$ reaction mixtures containing: $2.5 \mu \mathrm{l}$ 10X PCR buffer, $2 \mu \mathrm{ldNTP}, 0.5 \mu \mathrm{l}$ of each primer, $0.25 \mu \mathrm{l}$ of Taq DNA polymerase (Takara) and $5 \mu \mathrm{l}$ of DNA from cellular lysates. Amplification was carried out in a Thermal cycler (Applied Biosystem), as follows: an initial denaturation step of $95^{\circ} \mathrm{C}$ for $3 \mathrm{~min}, 30$ cycles of amplification ( $60 \mathrm{~s}$ of annealing at $37^{\circ} \mathrm{C}, 60 \mathrm{~s}$ of elongation at $72^{\circ} \mathrm{C}$, and $30 \mathrm{~s}$ of denaturation at $95^{\circ} \mathrm{C}$ ) and $7 \mathrm{~min}$ at $72^{\circ} \mathrm{C}$ for the last elongation. PCR primers pairs used in this study are shown in Table 1. An amount of $5 \mu \mathrm{l}$ of the PCR product was electrophoresed at $100 \mathrm{~V}$ on a $1 \%$ agarose gel. The documented sizes of the amplicons were 480 and 438 bp from sodA gene in Streptococci and Enterococci respectively (Poyart et al., 1998, 2000). 200 bp DNA Smartladder (Eurogentec) was used as molecular size marker and DNA of references strains was included.

\section{Streptococcus-specific PCR}

DNA identification analysis by PCR was followed with Streptococcus species-specific primers from $S$. thermophilus CNRZ1066 used as the positive control. The cellular lysates were obtained with the genereleaser ${ }^{\mathrm{TM}}$ (bio Ventures, inc.) from overnight cultures as described above and the following three primers pairs were used for this study (Table 1). The amplification profile included a denaturation step of $94^{\circ} \mathrm{C}$ for $5 \mathrm{~min}$, and then subjected to 30 cycles of $94^{\circ} \mathrm{C}$ for $30 \mathrm{~s}, 50^{\circ} \mathrm{C}$ for $30 \mathrm{~s}, 72^{\circ} \mathrm{C}$ for $1 \mathrm{~min}$ and a final soak at $4^{\circ} \mathrm{C}$. DNA fragments were determined by comparing the positive control bands from reference strains with amplified fragments of wild members within indigenous flora isolates. The documented bands of the amplicons were 470, 480 and 497 from glcK, dnaE and thrS respectively (Delorme et al., 2007). The presence of PCR products was determined by gel electrophoresis in $1 \%$ agarose gel containing ethidium bromide. Electrophoresis in
Tris-borate-EDTA was performed at $100 \mathrm{~V}$, and DNA Smartladder (Eurogentec) of $200 \mathrm{bp}$ was used as the molecular size marker.

\section{RESULTS}

\section{Biochemical and morphological characteristics}

12 strains were selected and presumptively identified as cocci thermophilic lactic acid bacteria (LAB). All the strains were Gram-positive, catalase negative and produced no gas from glucose. Eight strains did not grow at all or poorly in $6.5 \% \mathrm{NaCl}$, three of them were able to grow at $\mathrm{pH} 9.6$ and showed no or only weak growth on SB medium. Morphology cells were spherical, ovoid in short or means and long chain. Enterococci are reported to grow at $10^{\circ} \mathrm{C}$, but six strains presumptively identified in these genera by classical methods failed to do so. The contradictions were established in strains which grew well with pink colonies in SB agar but failed to grow in broth with $6.5 \% \mathrm{NaCl}$ and at $\mathrm{pH}$ 9.6. Therefore, another identification approach was necessary to clarify the taxonomic positions of these atypical isolates.

\section{Analysis of DNA amplicons products from sodA gene}

Identification by using the universal primers of sodA database of Gram-positive cocci is frequently reported particularly from genus and species of streptococci and enterococci. In this work, the specificity of the genus was determined by testing all isolates presumptively identified as thermophilic lactic acid bacteria in short and long chain. Only five strains reacted with sodAd1/sodAd2 genus universal primers, and occurred as a single product. One band of weak intensity at $438 \mathrm{bp}$ in the references and three isolates (LGM5, LGM6 and LGM7) and another band of strong intensity located approximately between $438-480 \mathrm{bp}$ was revealed in only the reference and two selected strains (LGM1 and LGM2). 
(a)

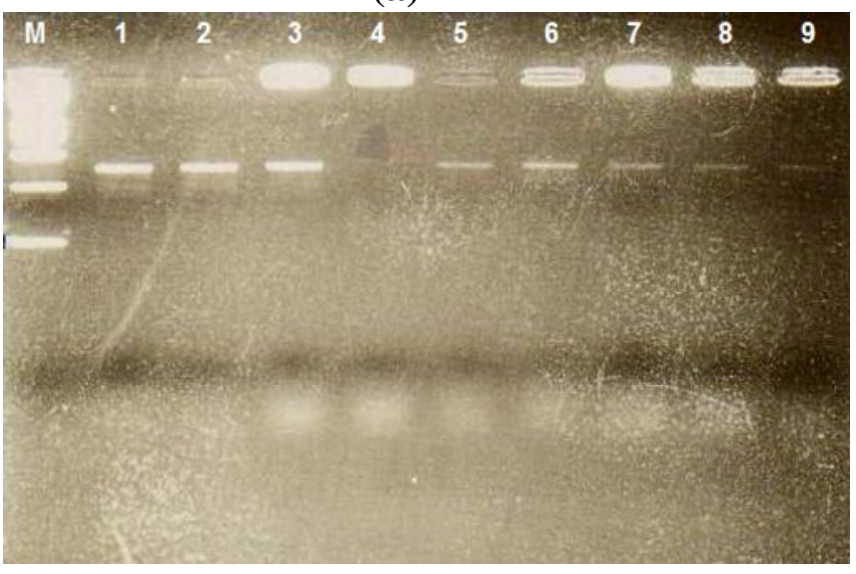

(c)

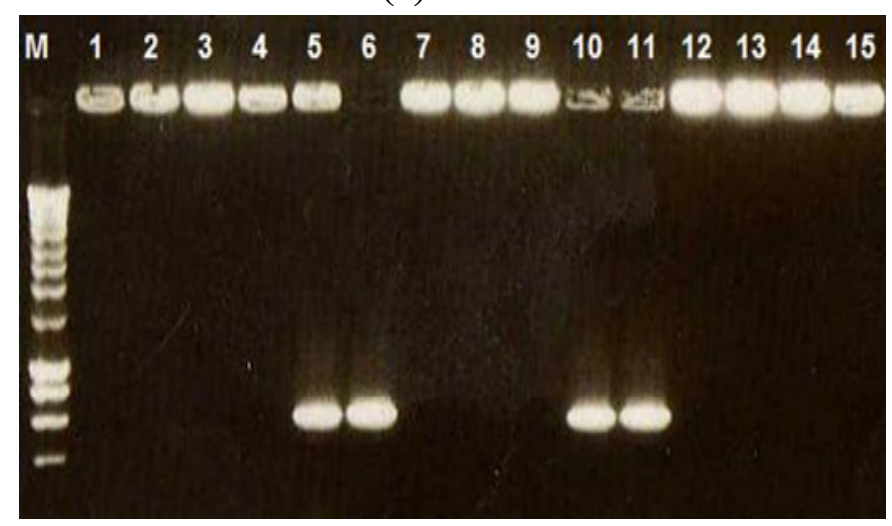

(b)

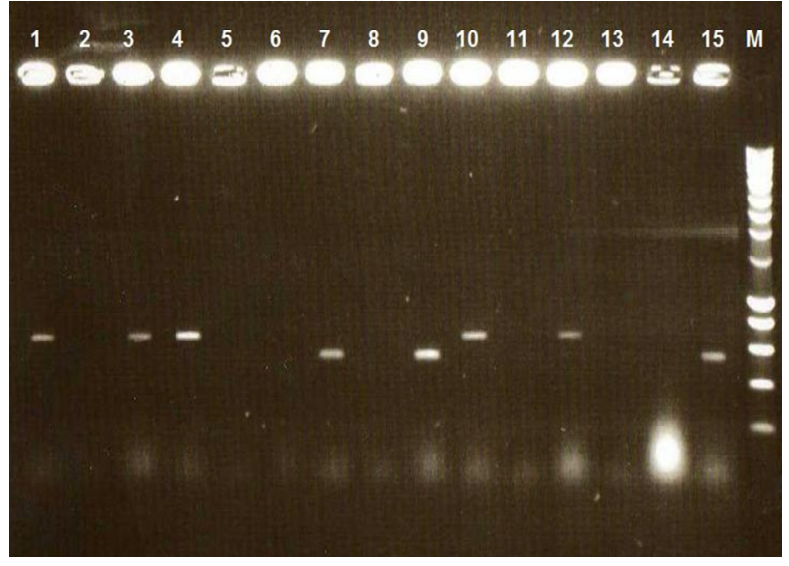

(d)

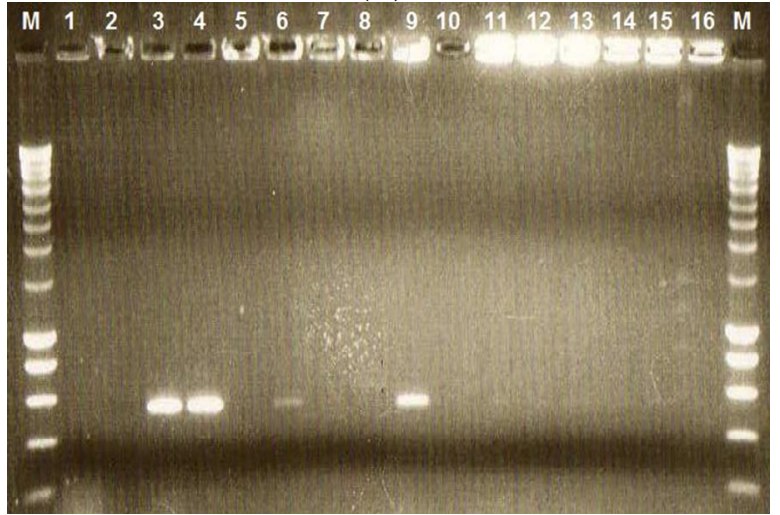

Figure 1. Genus and species-specific PCR amplifications for sodA gene. (a) Genus PCR with primer pair d1/d2. Lane M, 200-pb DNA molecular mass marker; lane 1, S. thermophilus CNRZ 1066 as positive control; lane 2, LGM1 isolate; lane 3, LGM2 isolate; lane 4, C. glutamicum ATCC 13032 as negative control; lane 5, LGM5 isolate; lane 6, LGM6 isolate; lane 7, LGM7 isolate; lane 8, E. faecalis JH2-2 as positive control; lane 9, E. faecium 64/3 as positive control. (b) Species-specific PCR with primer pair glcKup/glcK-dn. Lane M, 200-pb DNA molecular mass marker; lane 1, LGM5 isolate; lane 2, isolate 6; lane 3, LGM6 isolate; lane 4, LGM7 isolate; lane 5, isolate 7; lane 6, isolate 8; lane 7, LGM1; lane 8, isolate 9; lane 9, LGM2; lane 10, E.. faecalis JH2-2 as negative control; lane 11, isolate 10; lane 12 , E. faecium $64 / 3$ as negative control; lane 13, isolate 11; lane 14, isolate 12; lane 15, St. thermophilus CNRZ 1066 as positive control. (c) Species-specific PCR with primer pair dnaE-up/dnaE-dn. Lane M, 200-pb DNA molecular mass marker; lane 1, LGM5 isolate; lane 2, LGM6 isolate; lane 3, LGM7 isolate; lane 4, isolate 6; lane 5, LGM1; lane 6, LGM2; lane 7, isolate 7; lane 8, isolate 8; lane 9, isolate 9; lane 10, LGM3; lane 11, LGM4; lane 12, isolate 10; lane 13, isolate 11; lane 14, isolate 12; lane 15, E.. faecalis JH2-2 as negative control. (d) Species-specific PCR with primer pair thrSup/thrS-dn. Lane M, 200-pb DNA molecular mass marker; lane 1, Ent. faecium 64/3 as negative control; lane 2, E.. faecalis JH2-2 as negative control; lane 3, LGM1; lane 4, LGM2; lane 5, isolate 6; lane 6, LGM 3; lane 7, LGM5; lane 8, LGM6; lane 9, LGM4; lane 10, LGM7, lane 11, isolate 7, lane 12, isolate 8; lane 13, isolate 9; lane 14, isolate 10; lane 15, isolate 11; lane 16, isolate 12.

No significant common bands were found from other isolates, and from the control-negative strain $C$. glutamicum (Figure 1a). These results represent a similar profile and do not indicate the discriminating power of the universal primers of sodA gene PCR described here.

\section{Amplification using streptococcal species}

On the basis of the unclear results of phenotypic identification and the weak discriminating power of $\operatorname{sod} A$ gene between Streptococcus and Enterococcus genus, species-specific PCR of glcK, dnaE and thrS from streptococci were carried out to determine the taxonomic identification and to compare the isolates with reference strains. In one hand, the expected $470-p b$ band from glcK gene was revealed in the streptococci reference strain and two isolates (LGM1 and LGM2). However, a double product band was visualised also at approximately 600 bp in two reference enterococci strains and in three traditional butter isolates (LGM5, LGM6, and LGM7), while no significant bands were found from the other strains tested (Figure 1b). Two other strains suspected to be streptococci were confirmed by using primers of $\mathrm{glcK}$, 

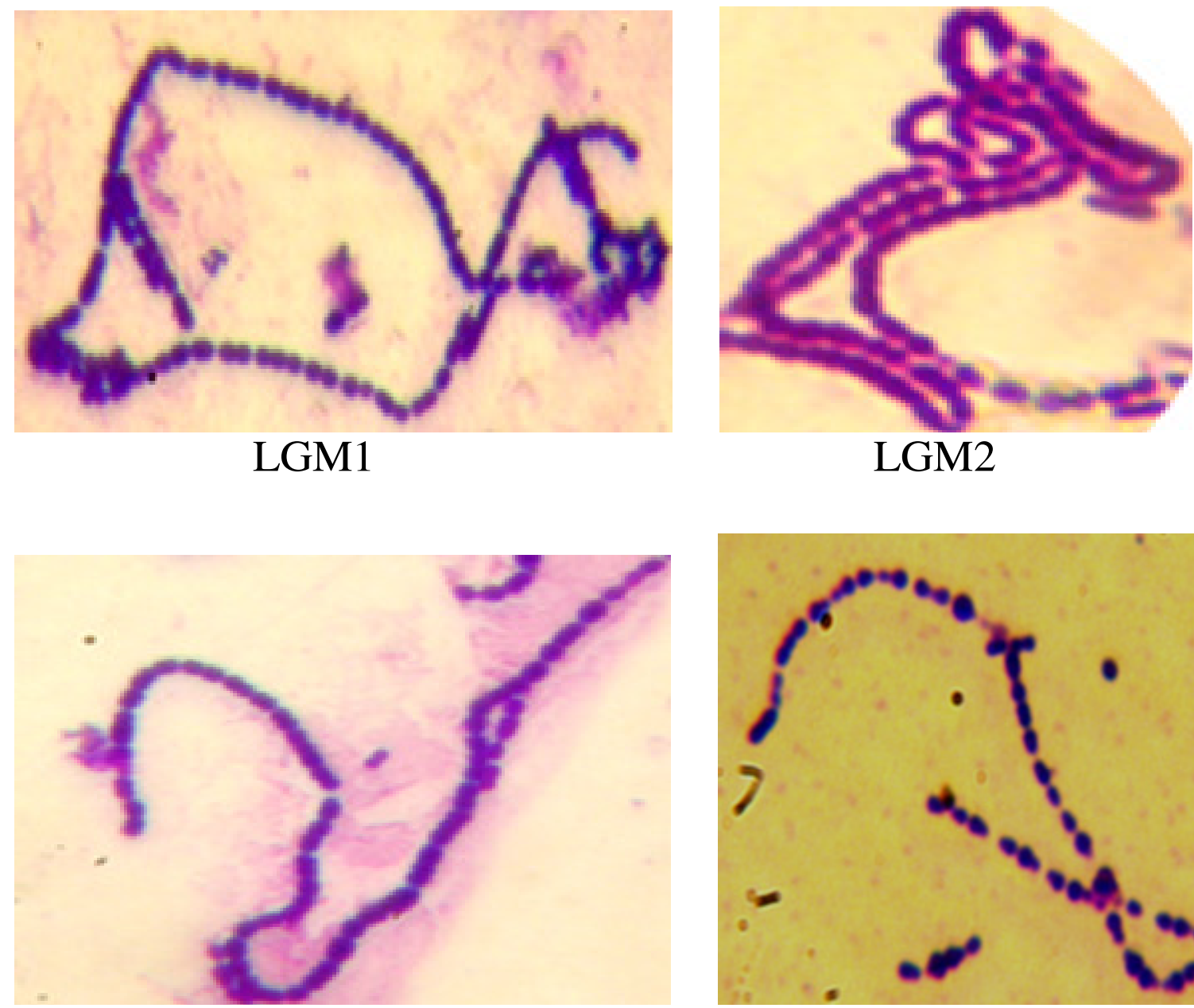

LGM3

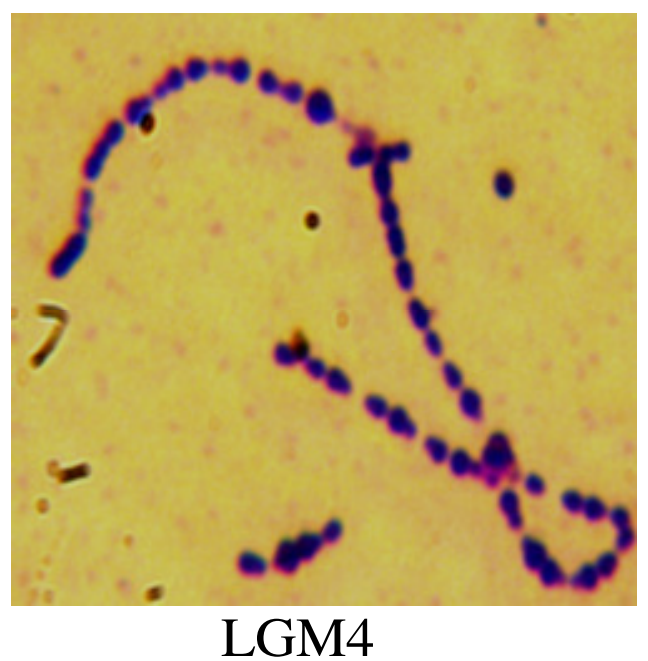

Figure 2. Microscopic cell morphology of wild Streptococcus thremophilus LGM1, LGM2, LGM3 and LGM4 isolated from traditional butter 'Smen' $(\times 1000)$.

LGM3 and LGM4, (results not shown).

On the other hand, the specific 480 and $497 \mathrm{bp}$ streptococci bands from $d n a E$ and thrS respectively were obtained in four isolates which reacted also with glcK from all isolates tested, (Figure 1c, d). Finally, in this study, we demonstrated that four isolates reacted with the three species-specific glcK, $d n a E$ and thrS amplicons used in this work, indicating that they are members of Streptococcus thermophilus which are provided from Algerian traditional butter 'Smen'. These results indicate the discriminating power of the glcK-up/glcK-dn, dnaEup/dnaE-dn and thrS-up/thrS-dn primers described in this work. This evidence allowed us to clearly differentiate Streptococcus thermophilus (Figure 2) from Enterococcus spp.

\section{DISCUSSION}

While the association of Streptococci and Enterococci with European fermented foods is well known (Moschetti et al., 1998; Cogan et al., 1997; Sengun et al., 2009; Secchi et al., 2011), little is known about the involvement of these bacteria in African fermented foods (Youssif et al., 2005). Streptococci were shown in this study to form a predominantly inhabitants of the microflora of fermented milk product 'Smen', as these bacteria could be isolated throughout the fermentation process. Enterococci were also present in 'Smen', they appear to be often associated with fermented products from Africa, although at a high incidence compared with other cocci lactic acid bacteria (LAB) (Mathara et al., 2004; Bensalah et al., 2006, 2009).

Streptococcus and Enterococcus are Gram-positive cocci, commonly recognized by their growth on Rogosa agar plates. These genera differ phenotypically; however, biochemical and physiological tests often give imprecise specifications. Due to complicated and uncertain identification, efforts have been made to develop simple, fast and discriminating methods for identification of 
Streptococcus from Enterococcus species (Moshetti et al., 1998). The result of this study demonstrates the necessity for use of molecular methods which is crucial for successful identification of unknown thermophilic cocci strains. PCR analysis is useful for clearly discriminating a multitude of species of LAB (like Streptococcus, Lactococcus and Enterococcus species) (Mannu and Paba, 2002; Bensalah et al., 2006, 2009). Species-specific PCR was previously used for the identification of clinical and food isolates of Enterococci and Streptococci (Poyart et al., 1998; Delorme et al., 2007).

The primers used for the sodA gene in this study gave a DNA profile almost similar to Streptococci and Enterococci; however, the use of three other primer pairs glcK, dnaE and thrE helped highlight different profiles and amplified the expected DNA bands. The loci chosen formed a suitable basis for DNA identification procedures and the housekeeping gene provided evidence and demonstrated that species-specific g/cK, dnaE and thrE discriminate among streptococci and enterococci isolates. PCR methods in this work proved to be useful for species identification and to reveal different patterns throughout this genus. We also attempted to show that phenotypic characterisation and amplified DNA amplicons using PCR analyses were quick, reliable and convenient methods to differentiate Streptococci from Enterococci. PCR assays developed here are technically affordable for laboratories that do not have easy access to more sophisticated or expensive procedures. Also, the genotypic and phenotypic analysis carried out on wild Streptococci and Enterococci isolated from traditional fermented 'Smen' highlighted diversity among strains. This study enabled the dominance biotypes in 'Smen' to be defined at each period of maturation and, it was found that the strains that dominated the first stage of ripening were not necessarily predominant in the later periods (Mannu et al., 2000).

To our knowledge, this is the first report on the occurrence, isolation and molecular identification of $S$. thermophilus in 'Smen' in Algeria, and further investigation into strain variability within species should be extended not only to more old samples but also, to dairy artisanal product from spontaneously fermented milk. The analysis of bacterial properties as synthesis of exopolysaccharides (Minic et al., 2007), proteolysis, aroma, acidifying power and antagonistic activity must be realised. These studies are of particular interest as they favour the isolation and selection of future cultures starters as $S$. thermophilus from traditional dairy products. It is, therefore, of great importance to preserve the genetic pool of strains of lactic acid bacteria in Africa.

\section{REFERENCES}

Alegría A, Alvarez-Martín P, Sacristán N, Fernández E, Delgado S, Mayo B (2009). Diversity and evolution of the microbial populations during manufacture and ripening of Casín, a traditional Spanish, starter-free cheese made from cow's milk. Int. J. Food Microbiol. 136: 44- 51.

Bensalah F, Maria-José F, Mouats A (2006). A rapid PCR based method to distinguish between Enterococcus species by using degenerate and species-specific sodA gene primers. Afr. J. Biotechnol. 5: 697-702.

Bensalah F, Delorme C, Renault P (2009). Characterisation of thermotolerant cocci from indigenous flora of 'leben' in Algerian arid area and DNA identification of atypical Lactococcus lactis strains. Curr. Microbiol. 59: 139-46.

Bouton Y, Guyot P, Grappin R (1998). Preliminary characterization of microflora of Comté cheese. J. Appl. Microbiol. 85: 123-31.

Cogan TM, Barbosa M, Beuvier E, Bianchi-Salvadore B, Cocconcelli PH, Fernandez PS, Gomez I, Kalantzoupoulos G, Ledda A, Medina M, Rea MC, Rodriguez E (1997). Characterisation of the lactic acid bacteria in artisanal dairy products. J. Dairy Res. 64: 409-421.

Coppola S, Parente E, Dumontet S, La Peccerella A (1998). The microflore of natural whey cultures utilized as strarters in the manufacture of Mazzarella cheese from water-buffalo milk. Le Lait. 68: 295-313.

Descheemaeker P, Lammens C, Pot B, Vandamme P, Goossens H (1997). Evaluation of arbitrarily primed PCR analysis and pulsed-field gel electrophoresis of large genomic DNA fragments for identification of enterococci important in human medicine. Int. J. Syst. Bacteriol. 47: 555-561.

Desmasures N, Mangin I, Corroler D, Guéguen M (1998). Characterization of lactococci isolated from milk produced in the Camembert region of Normandy. J. Appl. Microbiol. 85: 999-1005.

Delorme C, Poyart C, Ehrlich SD, Renault P (2007). Extent of horizontal gene transfer in evolution of Streptococci of the Salivarius group. J. Bacteriol. 189: 1330-1341.

Delorme C (2008). Safety assessment of dairy microorganisms: Streptococcus thermophilus. Int. J. Food Microbiol. 126: 274-277.

Devriese LA, Pot B, Collins MD (1993). Phenotypic identification of the genus Enterococcus and differentiation of phylogenetically distinct enterococcal species and species groups. J. Appl. Bacteriol. 75: 399408.

El-Baradei G, Delacroix-Buchet A, Ogier JC (2008). Bacterial biodiversity of traditional Zabady fermented milk. Int. J. Food Microbiol. 121: 295-301.

Elotmani F, Revol-Junelles AM, Assobhei O, Millière JB (2002). Characterisation of anti-Listeria monocytogenes bacteriocins from Enterococcus faecalis, Enterococcus faecium, and Lactococcus lactis strains isolated from Raib, a Moroccan traditional fermented milk. Curr. Microbiol. 44: 10-17.

Farber JM (1996). An introduction to the hows and whys of molecular typing. J. Food Prot. 59: 1091-1101.

Franz CM, von Holy A (1996). Thermotolerance of meat spoilage lactic acid bacteria and their inactivation in vacuum-packaged vienna sausages. Int. J. Food Microbiol. 29: 59-73.

Franz CMAP, Holzapfel WH, Stiles ME (1999). Enterococci at the crossroads of food safety? Int. J. Food Microbiol. 47: 1-24.

Giraffa G, Carminati D, Neviani E (1997). Enterococci isolated from dairy products: a review of risks and potential technological use. J. Food Prot. 60: 732-738.

Giraffa G, De Vecchi P, Rossi P, Nicastro G, Fortina MG (1998). Genotypic heterogeneity among Lactobacillus helveticus strains isolated from natural cheese starters. J. Appl. Microbiol. 85: 411-416.

Giraffa G, Olivari AM, Neviani E (2000). Isolation of vancomycinresistant Enterococcus faecium from Italian cheeses. Food Microbiol. 17: $671-677$

Hegazi FZ (1988). Proteolysis and electrophoretic pattern of casein of some fermented milks Nahrung. 32: 539-543.

Kühn I, Burman LG, Hæggman S, Tullus K, Murray BE (1995). Biochemical fingerprinting compared with ribotyping and pulsed-field gel electrophoresis of DNA for epidemiological typing of enterococci. J. Clin. Microbiol. 33: 2812-2817.

Mannu L, Paba A, Pes M, Scintu MF (2000). Genotypic and phenotypic heterogeneity among lactococci isolated from traditional Pecorino Sardo cheese. J. Appl. Microbiol. 89: 191-197.

Mannu L, Paba A (2002). A Genetic diversity of lactococci and 
enterococci isolated from home-made Pecorino Sardo ewes' milk cheese. J. Appl. Microbiol. 92: 55-62.

Martinez JL, Baquero F (2002). Interactions among strategies associated with bacterial infection: pathogenicity, epidemicity, and antibiotic resistance. Clin. Microbiol. Rev. 15: 647-679.

Mathara JM, Schillinger U, Kutima PM, Mbugua SK, Holzapfel WH (2004). Isolation, identification and characterisation of the dominant microorganisms of kule naoto: the Maasai traditional fermented milk in Kenya. Int. J. Food Microbiol. 94: 269-278.

Michaylova M, Minkova S, Kimura K, Sasaki T, Isawa K (2007). Isolation and characterization of Lactobacillus delbrueckii ssp. bulgaricus and Streptococcus thermophilus from plants in Bulgaria. FEMS Microbiol. Lett. 269: 160-169.

Minic Z, Marie C, Delorme C, Faurie JM, Mercier G, Ehrlich D, Renault $P$ (2007). Control of EpsE, the phosphoglycosyltransferase initiating exopolysaccharide synthesis in Streptococcus thermophilus, by EpsD tyrosine kinase. J. Bacteriol. 189: 1351-1357.

Moschetti G, Blaiotta G, Aponte M, Catzeddu P, Villani F, Deina P, Coppola S (1998). Random amplified polymorphic DNA and amplified ribosomal DNA spacer polymorphism: powerful methods to differentiate Streptococcus thermophilus strains. J. Appl. Microbiol. 85: 25-36.

Müller T, Ulrich A, Ott EM, Müller M (2001). Identification of plantassociated enterococci. J. Appl. Microbiol. 91: 268-278.

Ongol MP, Asano K (2009). Main microorganisms involved in the fermentation of Ugandan ghee. Int. J. Food Microbiol. 133: 286-291.

Poyart C, Berche P, Trieu-Cuot P (1995). Characterization of superoxide dismutase genes from Gram-positive bacteria by polymerase chain reaction using degenerate primers. FEMS Microbiol. Lett. 131: 41-45

Poyart C, Quesne G, Coulon S, Berche P, Trieu-Cuot P (1998). Identification of streptococci to species level by sequencing the gene encoding the manganese-dependent superoxide dismutase. J. Clin. Microbiol. 36: 41-47.

Poyart C, Quesnes G, Trieu-Cuot P (2000). Sequencing the gene encoding manganese-dependent superoxide dismutase for rapid species identification of enterococci. J. Clin. Microbiol. 38: 415-418.

Poyart C, Quesne G, Boumaila C, Trieu-Cuot P (2001). Rapid and accurate species-level identification of coagulase-negative staphylococci by using the sodA gene as a target. J. Clin. Microbiol. 39:4296-4301.
Ramos MS, Harlander SK (1990). DNA fingerprinting of lactococci and streptococci used in dairy fermentations. Appl. Microbiol. Biotechnol. 34: 368-374

Secchi N, Giunta D, Pretti L, García MR, Roggio T, Mannazzu I, Catzeddu P (2011). Bioconversion of ovine scotta into lactic acid with pure and mixed cultures of lactic acid bacteria. J. Ind. Microbiol. Biotechnol.. [Epub ahead of print]. $10: 1013-1019$

Sengun IY, Nielsen DS, Karapinar M, Jakobsen M (2009). Identification of lactic acid bacteria isolated from Tarhana, a traditional Turkish fermented food. Int. J. Food Microbiol. 135: 105-111.

Terzaghi BE, Sandine WE (1975). Improved medium for lactic streptococci and their bacteriophages. Appl. Microbiol. 29: 807-813.

Tissala-Timisjarvi A, Alatossava $T$ (1997). Development of oligonucleotide primers from the 16S-23S rRNA intergenic sequences for identifying different dairy and probiotic lactic acid bacteria by PCR. Int. J. Food Microbiol. 35: 49-56.

Tornadijo ME, Fresno JM, Bernardo A, Sarmiento RM, Carballo J (1995). Microbiological changes throughout the manufacturing and ripening of a Spanish goats' raw milk cheese (Armada variety). Le Lait. 75: 551-570.

Youssif NM, Dawyndt $P$, Abriouel $H$, Wijaya A, Schillinger $U$, Vancanneyt M, Swings J, Dirar HA, Holzapfel WH, Franz CM (2005). Molecular characterization, technological properties and safety aspects of enterococci from 'Hussuwa', an African fermented sorghum product. J. Appl. Microbiol. 98: 216-228.

Zolg J, Philippi-Schulz S (1994). The superoxide dismutase gene, a target for detection and identification of mycobacteria by PCR. J. Clin. Microbiol. 32: 2801-2812. 